\title{
INTERNATIONAL BUSINESS NEGOTIATION STRATEGIES BASED ON BARGAINING POWER ASSESSMENT: THE CASE OF ATTRACTING INVESTMENTS
}

\author{
Kęstutis PELECKIS \\ Department of International Economics and Business Management, Vilnius Gediminas \\ Technical University, Sauletekio al. 11, LT-10223 Vilnius, Lithuania \\ E-mail: k.peleckis@vgtu.lt (corresponding author)
}

Received 23 May 2016; accepted 04 September 2016

\begin{abstract}
At present business solutions are used for development and implementation of negotiating strategies for international business, which are not universally suitable for business development in all situations in context of globalization, with current challenges, which are characterized by increasing risk, uncertainty and cultural differences. The purpose of the research is to provide a theoretical model for developing and implementing international business negotiation strategies, based on bargaining power assessment, as well as to conduct an experiment and test the suitability and adaptability of the developed model in an international business negotiation situation - in case of attracting investments. Research methods - scientific literature analysis, comparative, logical analysis and synthesis, comparative and generalisation methods, mathematical and statistic data analysis methods. According to the results, the developed model can be used to reinforce international business negotiations and electronic business negotiations, as an independent systemic unit of the negotiation process (a measure that is autonomous or requires only partial intervention of the negotiator).
\end{abstract}

Keywords: negotiations, bargaining power, atracting investment, bargaining power assessment, strategic decisions, negotiation support.

JEL Classification: M16, M54.

\section{Introduction}

Contemporary business world has to encounter a huge variety of different cultures and their specifics, which requires adequate theoretical solutions for international business organisation and management. International business development under global conditions involves conducting business negotiations participated by representatives from all kinds of different cultures. This poses additional difficulties in developing strategic solutions and ensuring their support. Therefore, there is an obvious demand for adequate negotiation models, which take into the account the potential of the negotiating parties - their bargaining power. 
This article examines a model proposed by the author, the purpose of which is to help develop international business negotiation strategies, based on the assessment of bargaining power. This model will be tested in a typical international business negotiation environment - attracting investments. The model is based on the use of the game theory in order to find an optimum negotiation strategy and adapt the optimisation rules for international business negotiations in case of uncertainty. The purpose of this model is to develop and implement international business negotiation strategies based on bargaining power assessment, the analysis of strategic actions and strategic decision-making. The complexity and systematic nature of negotiation issues determines the necessity to consider the abundance of situations, processes and the criteria for evaluating negotiation potential. Here we will employ a multi-criteria analysis by using experts. According to the results, the developed model can be used to reinforce international business negotiations and electronic business negotiations, as an independent systemic unit of the negotiation process (a measure that is autonomous or requires only partial intervention of the negotiator). The problem is that management, as well as business management theory does not provide any theoretical solutions for evaluating bargaining power during international business negotiations, especially considering the possibilities of using negotiation support technology, which is rather important for international business development. The object of this research is the support for developing international business negotiation strategies, based on bargaining power assessment. The purpose of the research is to provide a theoretical model for developing and implementing international business negotiation strategies, based on bargaining power assessment, as well as to conduct an experiment and test the suitability and adaptability of the developed model in an international business negotiation situation - in case of attracting investments. Research methods - scientific literature analysis, comparative, logical analysis and synthesis, comparative and generalisation methods, mathematical and statistic data analysis methods.

\section{A model for developing an international business negotiation strategy, based on bargaining power assessment}

In our opinion, the development and implementation of negotiation strategies should be based on bargaining power assessment. However, the process of getting to know the situation may take place during the negotiation process, thus strategic tactics and actions (steps) may change on each new issue examined during the negotiations. The analysis of scientific literature (Ginevičius et al. 2014; Tamošiūnas 2011; Zavadskas et al. 2004) shows, that the application of heuristic algorithms in developing and implementing negotiation strategies in order to assess bargaining power and reflect on the process of negotiation itself, is rather promising. We will define a condition, that each negotiation issue will be examined only once, without coming back to it. The purpose of the heuristic algorithm will be to find the negotiating strategies-payoffs that bring the greatest total benefit for the negotiation process. In order to find them we will use various optimisation rules proposed by various scientists (Hurwitz, Wald, Savage and Niehaus, Bernoulli-Laplace, Bayes-Laplace, Hodges and Lehmann). We will arrange 
the negotiation issues from the most important to the least important, in order to make sure that the further course of the negotiations will not be in vain, e.g. to avoid situations of finding out that the other side of the negotiations is unable to implement the main criterion at the end of the negotiations (e.g. no one in the negotiation team has the authority to sign an agreement or a contract), thus making the entire negotiation a waste of time and effort.

The purpose of optimisation is rather complicated, because the individual most beneficial payoffs of the primary negotiation issues will not necessarily make the most beneficial aggregated payoff of all of the negotiation issues, which means that it is necessary to search for the most beneficial aggregated payoff of the entire negotiation process, i.e. to solve the issue of global optimisation. Example: certain negotiations revolve around three issues and each of these issues have several alternative solutions; although the payoffs of the first two issues were not very beneficial, choosing them has led to the best payoff of the third question, which results in the most beneficial possible final payoff of the entire negotiation process.

Having defined the priority list of our negotiation issues, note that each of the negotiation issues involves negotiating with a set of potential negotiation partners. Let's make that set a definite number, consisting of $t$ alternatives for each of the issues. Let's mark the alternatives of the issue $i$ as $b_{i, j}, j=1,2,3, \ldots, t_{i}$. Then we will mark the set of all the alternatives for the issue $i$ as $w_{i}=\left\{b_{i, 1}, b_{i, 2}, \ldots, b_{i, t_{i}}\right\}$, while $w_{1} \times w_{2} \times w_{3}, \ldots, w_{n}$ is the set of all possible negotiation scenarios, when each of the issues involves choosing one possible alternative, where $n$ is the number of the negotiation issues.

Having marked the beginning of the negotiation with a $b_{0}$, we can illustrate the entire process as a tree graph (Fig. 1), where the branch $H_{i, b_{i j}}$ marks the payoff of choosing the alternative $j$ in solving the issue $i$.

$$
\max _{k \in w_{1} \times w_{2} \times w_{3} \ldots w_{n}}\left(\sum_{i=1}^{n} H_{i, b_{i, j}}\right), j=1, \ldots,\left|w_{i}\right|,
$$

where: $H$ - the outcome of the negotiator's negotiation issue according to the chosen optimisation rule (Hurwitz, Wald, Werner, etc.); $n$ - the number of the negotiation issues (the subscript and superscript mark the beginning and the end of the negotiation issue). The superscript $b_{0}$ marks the beginning of the issue, the subscript $b_{i j}$ marks the alternative $j$ of the issue $i$, while the branch $H_{i, b_{i j}}$ marks the payoff of choosing the alternative $j$ as the solution to the issue $i, j \in w_{1} \times w_{2} \times w_{3}, \ldots, w_{n}$.

Further on we will use the Hurwitz formula in order to achieve the best payoff of the negotiator's negotiation issue wih the following uncertainties:

$$
\begin{aligned}
& H_{u}=\max _{u}\left[\gamma \min _{z} a_{u z}+(1-\gamma) \max _{z} a_{u z}\right] \text { (the best maximum solution); } \\
& H_{u}=\min _{u}\left[\gamma \max _{z} a_{u z}+(1-\gamma) \min _{z} a_{u z}\right] \text { (the best minimum solution), }
\end{aligned}
$$

where: $H$ - the payoff of the negotiator's negotiation issue according to Hurwitz rule; 
$a_{u z}$ - the payoff of the negotiator, which could be achieved upon making a move $u$ if the opponent makes the move $z$.

The set of the negotiator's moves is finite and consists of the number of s moves, which will be numbered as $u=1,2,3, \ldots, s$.

We assume that the set of the possible moves of the opponent is finite and consists of $k$ moves. We number these moves as $z=1,2,3, \ldots, k$.

$\gamma$ - the parameter of hope. $\gamma$ - the coefficient, changing from 0 to 1 . According to the formula, if $\gamma=1$, then the Hurwitz criterion equals with Waldo, i.e. the pessimistic criterion. If $\gamma=0$, the solution is optimistic, i.e. it allows to achieve the maximum payoff. The size of the coefficient $\gamma$ depends on which solution - optimistic or pessimistic - will be chosen by the negotiator. Perhaps the most acceptable coefficient for him would be $\gamma=0.5$, because this refers to choosing the middle between the pessimistic and optimistic. This game could be expressed in the so called payoff matrix and referred to as the matrix game. The form of the zero sum game:

$$
\Gamma=\left\{S_{1}, S_{2} ; A\right\}
$$

As we apply it for negotiation issues, we could say that the set of the first negotiator's strategies (pure strategies) is $S_{1}=\left\{S_{11}, S_{12}, \ldots, S_{1 s}\right\}$ while the set of the second negotiator's pure strategies is $S_{2}=\left\{S_{21}, S_{22}, \ldots, S_{2 k}\right\} S_{1}$ and $S_{2}$ They are finite and defined. The function of the payoffs is $A=\left\|a_{u z}\right\|_{s x k}$. The set of the negotiator's moves is finite and consists of the number of s moves, which will be numbered as $u=1,2,3, \ldots, s$. We assume that the set of the possible moves of our opponent is finite and consists of $k$ moves: $z=1,2,3, \ldots, k$.

The payoff matrix is used in order to find the most beneficial strategy to solve the negotiation issue. Each finite game has a solution related to pure or mixed strategies and the pure value of the solution can be expressed as the following: $\alpha \leq v \leq \beta$.

If $\alpha=\beta=v$ then the solution with clear strategies is the saddle point (only one optimal strategy for each player).

The number $\alpha$ is referred to as the lowest game value, $\beta$ - the highest game value, $v$ is referred to as the pure game value or the game value.

The application of the game theory for solving specific issues requires non-dimensional performance indicator values, which should indicate the ratio with the optimum value and be independent from the matrix type. We will use the exponential expression of the simple additive weighing (SAW) method by applying different exponents for the cases of the best minimum and best maximum criterion values, when the normal values are limited by the interval $[0 ; 1]$ :

$$
\begin{aligned}
& a_{u z}=\left(\frac{\min c_{u z}}{c_{u z}}\right)^{3} \text { if } \min _{u} c_{u z} \text { is favourable; } \\
& a_{u z}=\left(\frac{c_{u z}}{\max _{u} c_{u z}}\right)^{2} \text { if } \max _{u} c_{u z} \text { is favourable. }
\end{aligned}
$$


We will use the latter formula to normalise the indices of the negotiation issues, in order to facilitate the processing of the negotiation results and obtain comparative values.

As we have the primary data about the importance of the indices of the negotiation issues, it is necessary to determine the significance of the indices that characterise the negotiation issues (Ginevičius et al. 2014; Ginevičius et al. 2008; Lova et al. 2000; Mandow, Pérez de la Cruz 2003; Wibowo, Deng 2013; Azar 2014). The significance of the indices indicate how many times the usefulness of the index of one or another negotiation issue is larger (smaller) than the usefulness of another index. Keeping in mind the significance of the indices of the negotiation issues, we can define each of their values as follows (Ginevičius, Podvezko 2008a; Ginevičius, Podvezko 2008b; Ginevičius et al. 2008; Stewart et al. 2013; Ehtamo et al. 2001; Martín Ramos et al. 2010; Lourenzutti, Krohling 2014; Chang, Wu 2011; Azar 2014; Keršulienė 2008):

1. choosing the most significant index of the negotiation issue $-a_{g e r}$;

2. assigning 1 point for the best value of the negotiation issue $\left(a_{g e r}=1\right)$;

3. determining the percentage $\left(q_{v}\right)$ of how much the remaining indices $\left(b_{v}\right)$ are worst than the best option $\left(a_{g e r}=1\right)$;

4. assigning relative values to the index values $\left(a_{v}=1-q_{v} / 100\right)$;

5 . the relative values of all of the indices $\left(q_{v}\right)$ recalculated in a manner to make their sum equal to one:

$$
\sum_{v=1}^{m} q_{v}=1 ; v=1,2,3, \ldots, m .
$$

The multi-criteria assessment will be used in the application of game theory, when the negotiation issue involves examining more than one index. We will use the value of these normalised indices in the matrix game in order to find the payoff of the negotiation issue. The negotiation process can be illustrated in a graph (Fig. 1). The superscript $b_{0}$ marks the beginning of the issue, the subscript $b_{i j}$ marks the alternative $\mathrm{j}$ of the issue $\mathrm{i}$, while the branch $H_{i, b_{i j}}$ marks the payoff of choosing the alternative $\mathrm{j}$ as the solution to the issue i. Below you will see a global optimisation problem for a fixed number of negotiation issues, scheduled to be examined right before the negotiations.

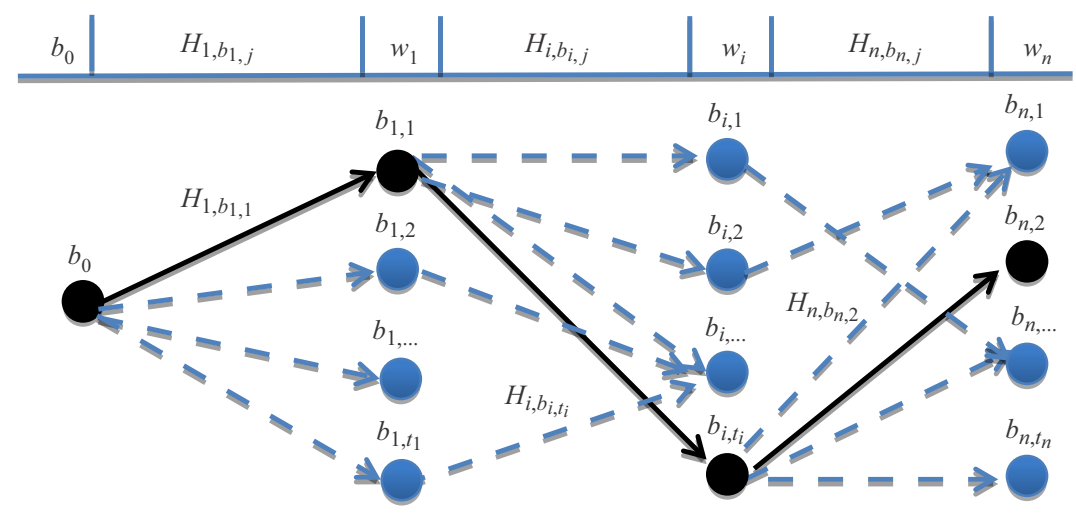

Fig. 1. Graph of negotiations

Source: composed by the author. 
Table 1 provides a theoretical model of an international business negotiation strategy, based on bargaining power assessment. The model provides a bargaining power assessment for three subjects: the negotiator, the negotiator's opponent and the negotiator's competitor. The bargaining power of these subjects will be assessed according to their significance in the negotiator's strategy, which is based on bargaining power assessment. These subjects directly influence the decision-making in creating a negotiation strategy.

Table 1. International business negotiation strategy and the preparation of the theoretical model based on bargaining power assessment

\begin{tabular}{|c|c|c|c|c|}
\hline & Interested parties & Negotiator & $\begin{array}{c}\text { Negotiator's } \\
\text { opponent }\end{array}$ & Negotiator's competitor \\
\hline No. & $\begin{array}{c}\text { The sequence } \\
\text { of applying } \\
\text { algorithm formulas }\end{array}$ & \multicolumn{3}{|c|}{ Mathematical expressions of the algorithm } \\
\hline 1 & $\begin{array}{l}\text { Peldschus } \\
\text { non-linear } \\
\text { normalisation of } \\
\text { the indices of the } \\
\text { negotiation issue. }\end{array}$ & $\begin{array}{l}a_{u z}=\left(\frac{\min _{u} c_{u z}}{c_{u z}}\right)^{3} \\
a_{u z}=\left(\frac{c_{u z}}{\max _{u} c_{u z}}\right)^{2}\end{array}$ & $\begin{array}{l}\text { if } \min _{u} c_{u z} \text { is favourable, } \\
\text { if } \max _{u} c_{u z} \text { is favourable. }\end{array}$ & \\
\hline
\end{tabular}

2 Multi-criteria $\quad$ Choosing the most significant index of the negotiation issue $-a_{\text {ger }}$; assessment of - Assigning the best value of the negotiation issue to 1 point $\left(a_{g e r}=1\right)$; the indices of the Determining the percentage $\left(q_{v}\right)$ of how much the remaining indices negotiation issue. $\quad\left(a_{v}\right)$ are worst than the best option $\left(a_{g e r}=1\right)$;

- Assigning relative values to index values $\left.a_{v}=1-q_{v} / 100\right)$;

- The relative values of all of the indices $\left(q_{v}\right)$ recalculated in a manner to make their sum equal to one:

$$
\sum_{v=1}^{m} q_{v}=1 ; v=1,2, \mathrm{~m} .
$$

3 Solving the game matrix in order to find the most beneficial strategy for finding the solution to the negotiation issue.
The form of the zero sum game:

$$
\Gamma=\left\{S_{1}, S_{2} ; A\right\} .
$$

As we apply it for negotiation issues, we could say that the set of the first negotiator's strategies (pure strategies) is $S_{1}=\left\{S_{11}, S_{12}, \ldots, S_{1 s}\right\}$ while the set of the second negotiator's pure strategies is $S_{2}=\left\{S_{21}, S_{22}, \ldots, S_{2 k}\right\} . S_{1}$ and $S_{2}$ are finite and defined. The function of the payoffs is $A=\left\|a_{u z}\right\|_{s x k}$.

The set of the negotiator's moves is finite and consists of the number of s moves, which will be numbered as $u=1,2,3, \ldots, s$.

We will assume that the set of the possible moves of the opponent is finite and consists of $\mathrm{k}$ moves. We will number these moves as $z=1$, $2,3, \ldots, k$.

Each finite game has a solution related to pure or mixed strategies and the pure value can be expressed as follows:

$$
\alpha \leq v \leq \beta \text {. }
$$

If $\alpha=\beta=v$, then the solution with clear strategies is the saddle point (only one optimal strategy for each player).

The number $\alpha$ is referred to as the lowest game value, $\beta$ - the highest game value, $v$ is referred to as the pure game value or the game value. 
End of Table 1

4 Using optimum rules in order to obtain the maximum payoff for the negotiation issue (using the Hurwitz rule as an example).

$$
\begin{aligned}
& H_{u}=\max _{u}\left[\gamma \min _{z} a_{u z}+(1-\gamma) \max _{z} a_{u z}\right] \text { the best maximum solution); } \\
& H_{u}=\min _{u}\left[\gamma \max _{z} a_{u z}+(1-\gamma) \min _{z} a_{u z}\right] \text { the best minimum solution), }
\end{aligned}
$$

where $H$ - the payoff of the negotiator's negotiation issue according to Hurwitz rule; $a_{u z}$ - the payoff of the negotiator, which could be achieved upon making a move $\mathrm{u}$ if the opponent makes the move $z$.

The set of the negotiator's alternative moves is finite and consists of the number of s moves, which will be numbered as $u=1,2,3, \ldots, s$.

We will assume that the set of the possible moves of the opponent is finite and consists of $\mathrm{k}$ moves. We will number these moves as $z=1$, $2,3, \ldots, k$.

$\gamma$-the parameter of hope. $\gamma$-the coefficient, changing from 0 to 1 .

5 Solving the optimisation problem in order to obtain the maximum payoff of the negotiations.

$$
\max _{k \in w_{1} \times w_{2} \times w_{3} \ldots w_{n}}\left(\sum_{i=1}^{n} H_{i, b_{i, j}}\right), j=1, \ldots,\left|w_{i}\right|,
$$

where: $H$ - the payoff of the negotiator's negotiation issue according to the Hurwitz rule; $n$ - the number of the negotiation issues (the subscript and superscript mark the beginning and the end of the negotiation issue). Having marked the beginning of the negotiation with $a b_{0}$, we can illustrate the entire process as a tree graph (Fig. 1), where the branch $H_{i, b_{i j}}$ marks the payoff of choosing the alternative $j$ in solving the issue $i$ :

$$
k \in w_{1} \times w_{2} \times w_{3}, \ldots, w_{n} .
$$

Having defined the priority list of our negotiation issues, note that each of the negotiation issues involves negotiating with a set of potential negotiation partners. Let's make that set a definite number, consisting of $t$ alternatives for each of the issues. Let's mark the alternatives of the issue $\mathrm{i}$ as $b_{i, j}, j=1,2,3, \ldots, t_{i}$. Then we will mark the set of all the alternatives for the issue $\mathrm{i}$ as $w_{i}=\left\{b_{i, 1}, b_{i, 2}, \ldots, b_{i, t_{i}}\right\}$ while $w_{1} \times w_{2} \times w_{3}$, $\ldots, w_{n}$ is the set of all possible negotiation scenarios, when each of the issues involves choosing one possible alternative, where $n$ is the number of the negotiation issues.

6 The comparison International business negotiation strategy based on bargaining power of the bargaining assessment.

power assessment and making the decision.

Source: composed by the author.

In the model the bargaining power assessment of all negotiation subjects and the preparation of the strategy is conducted as follows: a non-linear normalisation of the indices of the negotiation issue; multi-criteria assessment of the indices of the negotiation issue; using game matrix to obtain the most beneficial strategy for the negotiation issue; using optimum rules in order to obtain the maximum payoff of the negotiation issue; solving the optimisation problem in order to obtain the maximum negotiation payoff; finally, performing a comparative analysis of the bargaining power assessments and making the decision. 
We will use the developed model for preparing negotiation strategies to prepare international business negotiation strategies based on bargaining power assessment. This strategy-making model will later be applied in solving complex negotiation issues and problems. We will examine if the developed model is effective in supporting international business negotiations in cases of attracting investment.

\section{The empirical study methodology for the application and assessment of the model for preparing international business negotiation strategies based on bargaining power assessment}

The purpose of this paper is to conduct an empirical study to analyse the preparation of international business negotiation strategies based on bargaining power assessment in a typical field of business negotiations - attracting investments. In order to apply and test the model for preparing international business negotiation strategies based on bargaining power assessment, this study is necessary, because it may show the application opportunities and test its major parameters.

The empirical study involves the following research methods: logical analysis, forming logical conclusions, comparison, generalisation methods; mathematical and statistical data analysis methods are used to process and analyse the data obtained during the empirical study, the statistical analysis of the data was performed using the SPSS (Statistical Package for the Social Sciences) software. The methods of the game theory (Xu et al. 2012; Peña et al. 2014; Cevikel, Ahlatçıŏlu 2010; Panda, Das 2014; Zavadskas et al. 2004; Apynis 2007; Žilinskas 2007) and the multi-criteria assessment are used in order to evaluate the bargaining power of the business subjects participating at specific international business negotiations in order to choose efficient international business negotiation strategies. The assessment was performed using the MathLab software.

The study raised the following hypotheses:

H1: The practice of international business negotiations lacks tendencies and opportunities for substantial and adequate assessment of the bargaining power of various business subjects, taking into account the contemporary international and multicultural business environment, as well as the demands and opportunities of remote negotiation technology and electronic business development.

H2: International business negotiation strategies based on bargaining power assessment achieve better negotiation results, compared to negotiations that are not based on the bargaining power assessment.

We will attempt to prove the first (H1) and second (H2) hypotheses by analysing the preparation of international business negotiation strategies based on bargaining power assessment in a typical field of business negotiations - attracting investments.

The empirical study is focused on searching for the major parameters of the model and supporting its application opportunities.

The case of attracting investments is the most common situation in international business negotiations. The study is conducted according to the specifics of this field. After 
we test the suitability of this model for this typical case, we could discuss further studies on the application of this model in other areas. This study includes the methods of the game theory, using a heuristic algorithm (Lova et al. 2000; Mandow, Pérez de la Cruz 2003; Wibowo, Deng 2013; Azar 2014; Tamošiūnas 2011) and a multi-criteria assessment.

Multi-criteria assessment of negotiation issues involves using expert knowledge of each appropriate field. The subjects participating at the negotiations examined in this paper and their negotiation objects illustrate a typical case of business negotiations. The specific data of the negotiation subjects and objects are confidential in order to refrain from revealing their commercial secrets; therefore the availability of this study data is limited. However, the data that is available will be sufficient to illustrate the research process and results.

In order to test the model, the empirical study would benefit from using the methods of the game theory, because this enables to analyse the interaction of the objects that have their own individual objections. This is particularly important during international business negotiations, which involve interactions between people representing different cultures and thus resulting in a number of uncertainties. In order to develop an international business negotiation strategy based on the negotiators' bargaining power assessment, it would be beneficial to use the methods of the game theory that help to develop a model for creating a successful strategy. The game theory is defined as the entirety of methods for examining conflict situations and its purpose is to develop recommendations that enable the conflicting parties to make rational decisions (Bivainis 2011). We can apply the methods of the game theory if we can predict the options of the negotiating parties by analysing each of the options of each of the negotiating parties (Keršulienè 2008). Of course, in some cases of negotiations the game theory cannot always provide a full definition of the decision-making process; however, practice shows that the application of the methods of the game theory is a great tool, which helps to make reasonable and appropriate strategic solutions. In many business negotiations negotiators have to make their decisions with a number of uncertainties. Of course, the purpose of bargaining power assessment is to reduce this information deficit; however it's impossible to eliminate it due to the large number of variables. Therefore, we can use various optimum strategy calculation rules.

\section{The preparation of international business negotiation strategies based on bargaining power assessment in case of attracting investments}

This study examines the preparation of international business negotiation strategies based on bargaining power assessment in case of attracting investments. This will enable to check, if the model for developing negotiation strategies and its algorithm are suitable for supporting business negotiations based on bargaining power assessment. The cases of attracting investment have been examined by the following researchers: Soboleva et al. (2015), Krishtal and Lisovskaya (2015), Alexander and Matthias (2012), Tvaronavičienė and Lankauskienè (2011), Šimelytė and Antanavičienė (2014). Further 
on we conducted a bargaining power assessment of the interested subjects, which will be used in developing a strategy. In the study participated four business subjects. The participants and the context of the negotiations will be defined further on.

The situation and its context. One of the negotiating parties is searching for a factory producing luxurious bathroom and plumbing accessories for the purpose of selling them in Lithuania. This requires investments into opening and maintaining retail outlets in Vilnius, Kaunas and Klaipeda, including compensations for the exposition costs.

Interested parties:

Party 1 - the opponent. The opponent is one of the major Italian producers of bathroom and plumbing accessories. He has retailers in Lithuania. This partner is unsatisfied with the sales volumes of the current retailers and thus is searching for alternatives.

Party 2 - the negotiation subject in need of negotiation support. The negotiation subject is a Lithuanian retailer of bathroom and plumbing accessories, but so far he has been selling only economy-class products. He would like to start distributing goods for another client segment. However, his current premises are unsuitable. He has a huge experience of successful business. The negotiation payoffs will be evaluated based on this subject.

Party 3 - the competitor of the opponent. This is a relatively new Italian producer of bathroom and plumbing accessories; however, his investment possibilities are not as good as that of the Party 1. This party has been intensively looking for a partner in Lithuania.

Party 4 - the competitor of the opponent. This Italian producer of bathroom and plumbing accessories has been successfully selling luxurious bathroom accessories in Lithuania, but he would like to sell more than one manufacturer's goods.

The negotiation payoffs will be evaluated based on the business subject purchasing the goods. This international negotiation involves negotiating with other business subjects (formula 1). The criteria for evaluating the offers of other business subjects: delivery time (in months), price (euros), the risk of late payments (\%). The results of the delivery time, price and risk of late payments will be minimised (formula 5). The significance of the criteria for evaluating the negotiation issues will be determined by a team of experts (ten experts working in the field of attracting investments - project managers, managers, intermediaries and clients). The compatibility of the expert opinions is determined according to a concordance coefficient (Appendix 2, formulas 16-19). Then we outline the normalised solution matrices (formulas 5-6) according to the significance of the criteria and calculate the total value of the alternatives. Another step would be to compare the game outcome by adapting different optimisation rules (formula 4 and Appendix 2, formulas 7-15). We chose the following rules (Appendix 2, formulas 7-15): Hurwitz, Wald, Savage and Niehaus, Bernoulli-Laplace, Bayes-Laplace, Hodges and Lehmann. Accordingly, based on the applicable optimisation rules, we adopted the same output data for all rules: the coefficient of hope equals 0.5 ; the probability of the event -0.25 . Each subject provides 4 alternative proposals. However, the accuracy of the negotiation 
results depends on the possibly insufficient information. Therefore, in order to reduce the negative influence of the lack of information, we used the data of the business subjects' creditworthiness. The initial assessment data of the negotiation offers is provided in the Appendix 1. It involves choosing the optimum criteria and, accordingly, selecting the best indices. The assessment of the importance of the negotiation issues involves using expert opinions. The results of the expert group's assessment of the importance of the indices are provided in the Tables A.1 and A.2 of the Appendix 1. The compatibility of the expert opinions - the concordance coefficients (Appendix 2, formulas 16-19) are satisfactory. The next step involves providing normalised solution matrices (formulas 5-6) with adapted criteria significance. Tables A.3-A.5 (Appendix 1) provide game matrices that are normalised according to the significance of the criteria (formula 4). Figure 2 illustrates the comparison of the game results by adapting different optimisation rules.

The diagrams (Fig. 2) provide the summary of the negotiation support payoff results (according to formula 4, Appendix 2, and formulas 8-16 and 1), based on optimisation rules. They show which negotiator's offer has the greatest payoff according to different optimisation rules, as well as total payoffs of all of the issues. Figure 2 provides the payoffs of electronic business negotiation support for each issue according to different optimisation rules: Hurwitz, Wald, Savage and Niehaus, Bernoulli-Laplace, Bayes-Laplace, Hodges and Lehmann. The use of optimisation rules enables us to simulate various negotiation situations and find the largest, average and lowest payoffs. The principles and rules should be chosen by highly-qualified negotiators that are experienced in their field.

In order to determine, which of the options is the best, we should assess the specifics, goals and conditions of each of the tasks, however, in case of multiple negotiations and a lot of decision-making, it would be advisable to apply the principles of Bayes

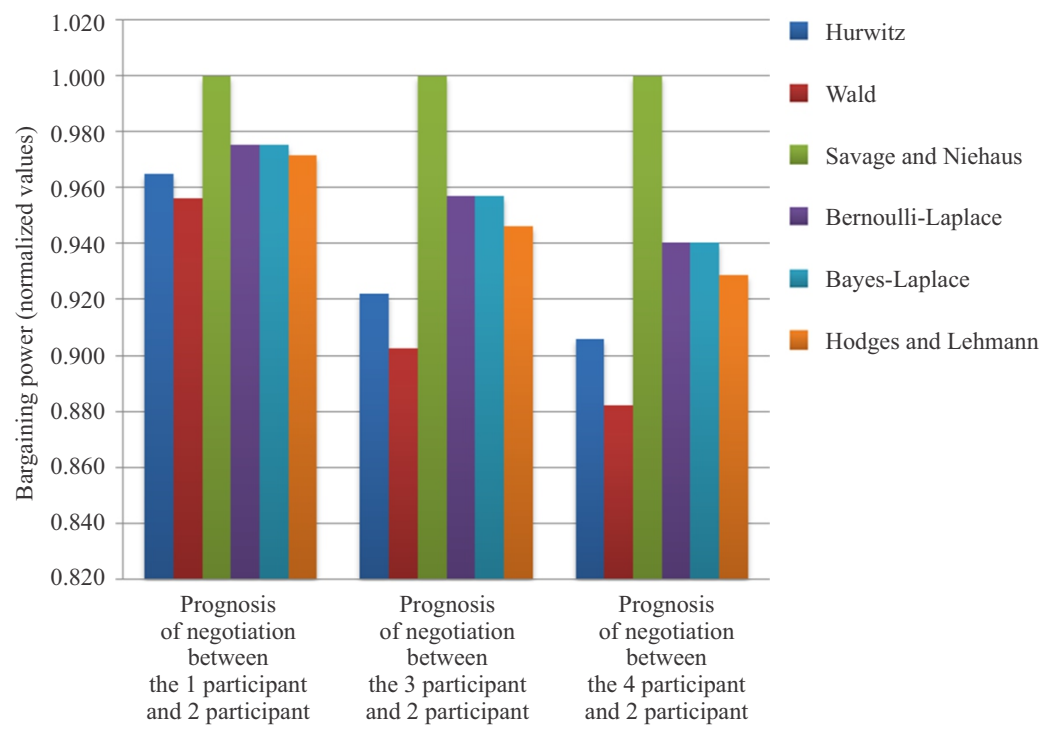

Fig. 2. The distribution of the negotiation payoffs in attracting investments according to different optimisation rules 
(Bayes-Laplace) and Hurwitz. If the negotiation is a one-time event, better keep to the mini-max and Savage-Niehaus principles. If in certain cases you cannot afford even the minimum risk, you should rely on the principle of Wald. If you can afford a partial risk, then calculate your optimum strategies according to the rules of Hodges and Lehman. The analysis of negotiation strategy support in electronic negotiations shows that the application of strategic principles may change with each individual negotiation issue. The diagrams illustrating the results showed that the most efficient optimisation rules that bring the largest payoffs are that of Savage and Niehaus, while the rule of Wald results in the lowest payoff. Accordingly, the rules of Hurwitz, Bernoulli-Laplace and BayesLaplace showed very similar results, while the rules of Hodges and Lehman provided a slightly larger payoff than the rule of Wald, which provided the lowest payoff. The total payoff results of all of the optimisation rules are provided in the Figure 3.

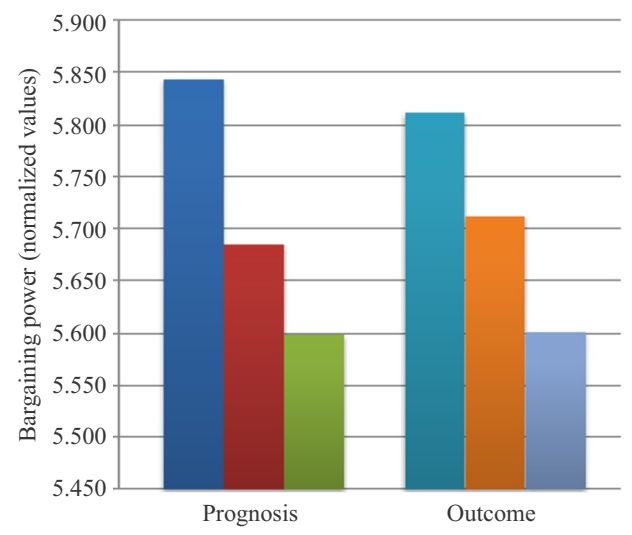

Fig. 3. The total results of the bargaining power assessment of the participants of international business negotiations in attracting investment

The participant 1 had the greatest bargaining power, while the bargaining power of his competitors was significantly smaller. Although the participant 2 did not use this negotiation support, he managed to conclude a transaction with the participant 1 . The results of this study reaffirm that the algorithm could be used to support negotiation strategies in attracting investments.

\section{Conclusions}

This study tested the model of developing and implementing negotiation strategies and its algorithm in a typical situation of international business negotiations: attracting investments. The study showed that using this algorithm helps to make much more efficient strategic decisions. The efficiency of using the algorithm is also illustrated by the fact that the actual bargaining power in the researched field of international business deviated from the predicted number by $2.01 \%$.

In order to apply and test the developed strategy preparation model based on bargaining power assessment, we conducted an empirical study in a typical international business 
environment - by analysing a case of international trade. The results show that the model helped to assess the bargaining power of the interested international business subjects and make strategically efficient decisions. It was determined that the use of the negotiation strategy model, which is based on bargaining power assessment, allowed to make more efficient strategic decisions that without using that model. Therefore, we could say that the results reaffirm the first and the second hypothesis. The perspectives of using the developed model at international business negotiations include: using the model as a measure for negotiation support or reducing information deficit, also as an autonomous engine of the negotiation process, for managing large quantities of information, as well as for improving communication conditions.

In this paper we developed and defined a model for creating and implementing negotiation strategies, based on bargaining power assessment. The paper also defines the empirical study methodology for the application and assessment of the model for preparing international business negotiation strategies based on bargaining power assessment. Research limitations are that this model is tested at the case of attracting investments, so it would be useful to adapt and test this model in other typical international business negotiation environments: services, transport and logistics, investments, e-trade.

Based on the conclusions of the study we could say that the model for developing international business negotiation strategies may be used for negotiations, which involve attracting investments both as an autonomous measure, as well as a measure, which partially requires the negotiator's intervention. This model for developing negotiation strategies may be used for negotiation support by using various data bases. The results of the study may be used in creating international business negotiation strategies, taking into account global, international and multicultural cooperation principles. The integrated model for supporting decision-making during international business negotiations enables an adequate assessment of the bargaining power of the negotiating and interested parties. It also helps to create an integrated view of the factors that actually influence the negotiation results, the specifics of cooperation in different countries and cultures, as well as optimise the processes of creating and implementing international business negotiation strategies with the aim to make the most of the bargaining power for international business development under contemporary conditions.

Recently management tasks are usually optimised using heuristic optimisation methods, based on various paradigms of searching for solutions, which are often developed based on analogies with nature, by adapting artificial intelligence technology, etc. The application of heuristic algorithms in negotiations is useful for the nature of negotiations itself - knowledge of the bargaining power is acquired during the negotiation process thus reducing the hindering factor of uncertainty and using the rules of calculating optimum strategies. These tasks may be solved by a number of heuristic algorithms, which calculate the optimum possible result that can be achieved in a certain time. Heuristic algorithms are used for optimisation and help to achieve high quality. Negotiations are based on gradual process of getting more knowledge on the bargaining power of the other side of the negotiations, thus, each issue may be solved using different tactics. 
Therefore, the application of heuristic algorithms may contribute to efficient negotiation management. The principles and rules should be selected by highly-qualified and experienced professionals, consultants and negotiators in order to determine, which of the options is the best, taking into the account the specifics, goals and conditions of each task. The study conducted by the author and its results discussed in this paper only reaffirm the conclusion made earlier.

\section{References}

Alexander, P. G.; Matthias, W. 2012. Emerging economies' attraction of foreign direct investment, Emerging Markets Review 13(2): 210-229. http://dx.doi.org/10.1016/j.ememar.2012.03.005 Apynis, A. 2007. Lošimu teorija [The Game Theory]. Vilnius: Vilnius University Press.

Azar, O. H. 2014. The default heuristic in strategic decision making: when is it optimal to choose the default without investing in information search?, Journal of Business Research 67(8): 1744-1748. http://dx.doi.org/10.1016/j.jbusres.2014.02.021

Bivainis, J. 2011. Vadyba studentams: mokomoji knyga [Management for students: training book]. Vilnius: Technika. http://dx.doi.org/10.3846/1229-S

Cevikel, A. C.; Ahlatçığlu, M. 2010. Solutions for fuzzy matrix games, Computers \& Mathematics with Applications 60(3): 399-410. http://dx.doi.org/10.1016/j.camwa.2010.04.020

Chang, Y. H.; Wu, T. T. 2011. Dynamic multi-criteria evaluation of co-evolution strategies for solving stock trading problems, Applied Mathematics and Computation 218(8): 4075-4089.

http://dx.doi.org/10.1016/j.amc.2011.09.032

Ehtamo, H.; Kettunen, E.; Hämäläinen, R. P. 2001. Searching for joint gains in multi-party negotiations, European Journal of Operational Research 130(1): 54-69.

http://dx.doi.org/10.1016/S0377-2217(00)00019-9

Ginevičius, R.; Podvezko, V. 2008a. Daugiakriterinio vertinimo būdų suderinamumas [The compatibility of the Multi-criteria evaluation methods], Verslas: Teorija ir praktika 9(1): 73-80.

Ginevičius, R.; Podvezko, V. 2008b. Daugiakriterinio vertinimo taikymo galimybès kiekybiniam socialinių reiškinių vertinimui [Multi-criteria assessment application opportunities in qualitative assessment of social phenomena], Verslas: Teorija ir praktika 9(2): 81-87.

Ginevičius, R.; Podvezko, V.; Raslanas, S. 2008. Evaluating the alternative solutions of wall insulation by multicriteria methods, Journal of Civil Engineering and Management 14(4): 217-226. http://dx.doi.org/10.3846/1392-3730.2008.14.20

Ginevičius, R.; Suhajda, K.; Petraškevičius, V.; Šimkūnaitè, J. 2014. Lithuanian experience of quantitative evaluation of socioeconomic systems position by multicriteria methods, Procedia Social and Behavioral Sciences 110(24): 952-960. http://dx.doi.org/10.1016/j.sbspro.2013.12.941

Keršulienè, V. 2008. Užsakovo ir rangovo racionalaus ginču sprendimo būdo nustatymas lošimu teorijos metodais [Determining a rational method of finding solutions in disputes between contractors and clients based on the Game Theory]: PhD dissertation. Vilnius Gediminas Technical University.

Krishtal, I.; Lisovskaya, E. 2015. Attraction of foreign capital, investment projects and mechanism of production sharing agreements, Procedia - Social and Behavioral Sciences 166(7): 127-130. http://dx.doi.org/10.1016/j.sbspro.2014.12.496

Tvaronavičienè, M.; Lankauskienė, T. 2011. Plausible foreign direct investment' impact on sustainable development indicators of differently developed countries, Journal of Security and Sustainability Issues 1(1): 27-38. http://dx.doi.org/10.9770/jssi.2011.1.1(3) 
Lourenzutti, R.; Krohling, R. A. 2014. The hellinger distance in multicriteria decision making: an illustration to the TOPSIS and TODIM methods, Expert Systems with Applications 41(9): 4414-4421. http://dx.doi.org/10.1016/j.eswa.2014.01.015

Lova, A.; Maroto, C.; Tormos, P. 2000. A multicriteria heuristic method to improve resource allocation in multiproject scheduling, European Journal of Operational Research 127(2): 408-424. http://dx.doi.org/10.1016/S0377-2217(99)00490-7

Mandow, L.; Pérez de la Cruz, J. L. 2003. Multicriteria heuristic search, European Journal of Operational Research 150(2): 253-280. http://dx.doi.org/10.1016/S0377-2217(02)00517-9

Martín Ramos, J. M.; López García, D.; Gómez-Bravo, F.; Blanco Morón, A. 2010. Application of multicriteria decision-making techniques to manoeuvre planning in nonholonomic robots, $E x$ pert Systems with Applications 37(5): 3962-3976. http://dx.doi.org/10.1016/j.eswa.2009.11.019

Panda, A.; Das, C. B. 2014. Multi-choice linear programming for matrix game, Applied Mathematics and Computation 237(15): 411-418. http://dx.doi.org/10.1016/j.amc.2014.03.017

Peña, J.; Lehmann, L.; Nöldeke, G. 2014. Gains from switching and evolutionary stability in multi-player matrix games, Journal of Theoretical Biology 346(7): 23-33.

http://dx.doi.org/10.1016/j.jtbi.2013.12.016

Šimelytè, A.; Antanavičienè, J. G. 2014. Formation of foreign direct investment policy: case of Estonia, Inžinerine ekonomika 25(2): 177-185.

Soboleva, Y. P.; Lygina, N. I.; Rudakova, O. V. 2015. Human potential as an element of innovative-investment attraction of the regions, Procedia Economics and Finance 24: 666-674.

http://dx.doi.org/10.1016/S2212-5671(15)00670-X

Stewart, T. J.; French, S.; Rios, J. 2013. Integrating multicriteria decision analysis and scenario planning - review and extension, Omega 41(4): 679-688.

http://dx.doi.org/10.1016/j.omega.2012.09.003

Tamošiūnas, L. 2011. Euristiniu paieškos algoritmu tyrimas ir taikymas atviro kodo geografinèse informacinese sistemose [Research and implementation of heuristic search algorithms in open source geographic information systems]: Master's thesis. Kaunas University of Technology.

Wibowo, S.; Deng, H. 2013. Consensus-based decision support for multicriteria group decision making, Computers \& Industrial Engineering 66(4): 625-633.

http://dx.doi.org/10.1016/j.cie.2013.09.015

Xu, Y.; Liu, J.; Zhong, X.; Chen, S. 2012. Lattice-valued matrix game with mixed strategies for intelligent decision support, Knowledge-Based Systems 32: 56-64.

http://dx.doi.org/10.1016/j.knosys.2011.08.019

Zavadskas, E. K.; Peldschus, F.; Ustinovičius, L.; Turskis, Z. 2004. Lošimu teorija statybos technologijoje ir vadyboje [The Game Theory in construction technology and management]: Monography. Vilnius: Technika.

Žilinskas, K. 2007. Matematinis programavimas. I dalis. Tiesinis programavimas [Mathematical programming I. Linear programming]. Šiauliai: Šiauliai University. 


\section{APPENDIX 1}

\section{Specification of research calculations}

Table A.1. The matrix of the expert evaluation

\begin{tabular}{ccccc}
\hline \multicolumn{6}{c}{ Estimation of the significance of the criteria by negotiation expert group } \\
\hline \multicolumn{5}{c}{ Criteria } \\
\hline Experts & 1 & 2 & 3 & Sum \\
\hline 1 & 0.1 & 0.6 & 0.3 & 1 \\
\hline 2 & 0.2 & 0.5 & 0.3 & 1 \\
\hline 3 & 0.1 & 0.6 & 0.3 & 1 \\
\hline 4 & 0.2 & 0.7 & 0.1 & 1 \\
\hline 5 & 0.2 & 0.5 & 0.3 & 1 \\
\hline 6 & 0.1 & 0.5 & 0.4 & 1 \\
\hline 7 & 0.2 & 0.5 & 0.3 & 1 \\
\hline 8 & 0.2 & 0.5 & 0.3 & 1 \\
\hline 9 & 0.1 & 0.6 & 0.3 & 10 \\
\hline 10 & 0.2 & 0.6 & 0.2 & \\
\hline Sum & 1.6 & 5.6 & 2.8 & 1 \\
\hline
\end{tabular}

Table A.2. The matrix of the expert evaluation rankings

\begin{tabular}{ccccc}
\hline \multicolumn{7}{c}{ The matrix of the expert evaluation rankings } \\
\hline \multicolumn{5}{c}{ Criteria } \\
\hline Experts & 1 & 2 & 3 & Sum \\
\hline 1 & 3 & 1 & 2 & 6 \\
\hline 2 & 3 & 1 & 2 & 6 \\
\hline 3 & 3 & 1 & 2 & 6 \\
\hline 4 & 2 & 1 & 3 & 6 \\
\hline 5 & 3 & 1 & 2 & 6 \\
\hline 6 & 3 & 1 & 2 & 6 \\
\hline 7 & 3 & 1 & 2 & 6 \\
\hline 8 & 3 & 1 & 2 & 6 \\
\hline 9 & 3 & 1 & 2 & 6 \\
\hline 10 & 2 & 1 & 2 & 5 \\
\hline Sum & 28 & 10 & 21 & 59 \\
\hline Rank sum average & 20 & 20 & 20 & Sum \\
\hline Deviation & 64 & 100 & 1 & 165 \\
\hline Concordance rate W & & 0.825 & & \\
\hline
\end{tabular}


K. Peleckis. International business negotiation strategies based on bargaining power assessment ...

Table A.3. Normalised decision-making matrix

(negotiations between the Participant No. 1 and Participant No. 2)

\begin{tabular}{|c|c|c|c|c|}
\hline \multicolumn{5}{|c|}{ Normalised decision-making matrix } \\
\hline \multirow[b]{2}{*}{ Alternatives } & \multicolumn{3}{|c|}{ Criteria } & \multirow[b]{2}{*}{$\begin{array}{l}\text { Sum by } \\
\text { significance }\end{array}$} \\
\hline & $\begin{array}{c}\text { Duration of activity, } \\
\text { years }\end{array}$ & Investment, EUR & $\begin{array}{c}\text { Turnover, mln. } \\
\text { EUR }\end{array}$ & \\
\hline A1R1 & 1.000 & 0.960 & 1.000 & 0.978 \\
\hline A1R2 & 1.000 & 0.941 & 1.000 & 0.967 \\
\hline A2R1 & 1.000 & 1.000 & 1.000 & 1.000 \\
\hline A2R2 & 1.000 & 0.922 & 1.000 & 0.956 \\
\hline W11 & A1 & $\mathrm{A} 2$ & & \\
\hline $\mathrm{R} 1$ & 0.978 & 1.000 & & \\
\hline $\mathrm{R} 2$ & 0.967 & 0.956 & & \\
\hline
\end{tabular}

Table A.4. Normalised decision-making matrix

(negotiations between the Participant No. 3 and Participant No. 2)

\begin{tabular}{ccccc}
\hline \multicolumn{5}{c}{ Normalised decision-making matrix } \\
\hline \multirow{3}{*}{ Alternatives } & \multicolumn{5}{c}{ Criteria } \\
\cline { 2 - 5 } & $\begin{array}{c}\text { Duration of activity, } \\
\text { years }\end{array}$ & $\begin{array}{c}\text { Investment, } \\
\text { EUR }\end{array}$ & $\begin{array}{c}\text { Turnover, mln. } \\
\text { EUR }\end{array}$ & $\begin{array}{c}\text { Sum by } \\
\text { significance }\end{array}$ \\
\hline A1R1 & 1.000 & 0.911 & 1.000 & 0.950 \\
\hline A1R2 & 1.000 & 0.955 & 1.000 & 0.975 \\
\hline A2R1 & 1.000 & 1.000 & 1.000 & 1.000 \\
\hline A2R2 & 1.000 & 0.826 & 1.000 & 0,903 \\
\hline \hline W12 & A1 & A2 & \\
\hline R1 & 0.950 & 1.000 & \\
\hline R2 & 0.975 & 0.903 & \\
\hline
\end{tabular}

Table A.5. Normalised decision-making matrix

(negotiations between the Participant No. 4 and Participant No. 2)

\begin{tabular}{ccccc}
\hline \multicolumn{5}{c}{ Normalised decision-making matrix } \\
\hline \multirow{3}{*}{ Alternatives } & \multicolumn{4}{c}{ Criteria } \\
\cline { 2 - 5 } & $\begin{array}{c}\text { Duration of activity, } \\
\text { years }\end{array}$ & Investment, EUR & $\begin{array}{c}\text { Turnover, mln. } \\
\text { EUR }\end{array}$ & $\begin{array}{c}\text { Sum by } \\
\text { significance }\end{array}$ \\
\hline A1R1 & 1.000 & 0.790 & 1.000 & 0.882 \\
\hline A1R2 & 1.000 & 0.857 & 1.000 & 0.920 \\
\hline A2R1 & 1.000 & 0.927 & 1.000 & 0,959 \\
\hline A2R2 & 1.000 & 1.000 & 1.000 & 1.000 \\
\hline \hline W13 & $\mathrm{A} 1$ & $\mathrm{~A} 2$ & \\
\hline R1 & 0.882 & 0.959 & \\
\hline R2 & 0.920 & 1.000 & \\
\hline
\end{tabular}




\section{APPENDIX 2}

\section{Formulas for optimisation rules}

Wald rule

$$
S_{1}^{*}=\left\{S_{1 i} \mid S_{1 i} \in S_{1} \cap\left\{S_{1 i 0} a_{i 0 j 0} \max _{i} \min _{j} a_{i j}\right\}\right\}
$$

\section{Hurwicz rule}

$$
\begin{gathered}
A_{j}=\max _{i}\left((1-\lambda) \min _{j} a_{i j}+\lambda \max _{j} a_{i j}\right), \\
A_{j}=\min _{i}\left((1-\lambda) \max _{j} a_{i j}+\lambda \min _{j} a_{i j}\right) . \\
S_{1}^{*}=\left\{S_{1 i} \mid S_{1 i} \in S_{i} \cap\left\{S_{1 i 0} \mid h_{i 0}=\max _{i} h_{i} ; h_{i}=\max _{i}(1-\lambda) \min _{j} a_{i j}+\lambda \max _{j} a_{i j} ; 0 \leq \lambda \leq 1\right\}\right\} .
\end{gathered}
$$

Savage- Niehaus rule

$$
S_{1}^{*}=\left\{S_{1 i} \mid S_{1 i} \in S_{i} \cap\left\{S_{1 i 0} \mid r_{i 0 j 0}=\min _{i} \max _{j} r_{i j}\right\},\right.
$$

where: $r=\overline{1 m} ; s=\overline{1, n}$.

Bernoulli-Laplace rule

$$
S_{1}^{*}=\left\{S_{1 i} \mid S_{1 i} \in S_{i} \max _{i}\left(1 / n \sum_{i=1}^{n} a_{i j}\right)\right\} \text {. }
$$

Bayes-Laplace rule

$$
S_{1}^{*}=\left\{S_{1 i} \mid S_{1 i} \in S_{i} \cap \max _{i}\left(\sum_{j=1}^{n} q_{j} a_{i j}\right) \cap \sum_{j=1}^{n} q_{j}=1\right\} .
$$

\section{Hodges-Lehmann rule}

$$
S_{1}^{*}=\left\{\frac{S_{1 i}}{S_{1 i}} \in S_{i} \cap \max _{i}\left[\begin{array}{c}
\left.\lambda \sum_{j=1}^{n} q_{j} a_{i j}=(1-\lambda) \min _{j} a_{i j}\right] \\
\bigcap^{0 \leq \lambda \leq 1}
\end{array}\right] .\right.
$$

\section{Werner rule}

$S_{1}^{*}=\left\{S_{1 i} \mid S_{1 i} \in S_{i} \cap\left\{S_{1 i 0} \mid a_{i 0}=\max _{i \in M_{\varepsilon}} a_{i j} ; M_{\varepsilon i}=\left\{i \mid \max _{i} a_{i j} \min _{j} a_{i j}-a_{i j} \leq \varepsilon\right\} ; \max _{j} a_{i j} \geq \max _{j} a_{i 0 j}\right\}\right.$,

where: $\varepsilon-$ the extent of the risk. 


\section{Concordance coefficient}

Concordance coefficient $\mathrm{W}$ is calculated by the following formula (Ginevičius et al. 2008):

$$
W=\frac{12 S}{r^{2} m\left(m^{2}-1\right)} .
$$

where $r$ - the number of experts; $m$ - evaluates the indicators number number.

The value $S$ is calculated as follows:

Calculating assessments made by experts $e_{i k}$ each indicator rank-sum $e_{i}$ by the following formula (Ginevičius et al. 2008):

$$
e_{i}=\sum_{k=1}^{r} e_{i k} .
$$

The total number of grades on average $\bar{e}$ by the following formula (Ginevičius et al. 2008):

$$
\bar{e}=\frac{\sum_{i=1}^{m} e_{i}}{m} .
$$

Value $S$, rank-sum $e_{i}$ deviations from the general average $\bar{e}$ the sum of the squares counted by the following formula (Ginevičius et al. 2008):

$$
S=\sum_{i=1}^{m}\left(e_{i}-\bar{e}\right)^{2} .
$$

Kestutis PELECKIS, Doctor of Social Sciences, is a Lecturer of Department of International Economics and Business Management, Vilnius Gediminas Technical University. Scientific interests: negotiation strategy, competitiveness, multiculturalism. 